\title{
Shepherd Ivory Franz: His contributions to neuropsychology and rehabilitation
}

\author{
VICTOR A. COLOTLA \\ Workers' Compensation Board of British Columbia, Vancouver, British Columbia, Canada \\ and \\ PAUL BACH-Y-RITA \\ University of Wisconsin, Madison, Wisconsin
}

\begin{abstract}
Shepherd I. Franz was an important figure in psychology of the last century, and historians of psychology have given recognition to much of his work. However, his experimental work with animals and his pioneer investigations in experimental and clinical neuropsychology have been largely ignored. This article reviews his conceptual, assessment, and treatment contributions, including (1) his pioneering work on the use of learned behavior as a baseline for the study of cerebral ablations, (2) his interest in brain plasticity, (3) his development of comprehensive psychological assessment methods, and (4) his work on the rehabilitation of neurological patients with techniques derived from his animal experiments. His work predated much of what is now part of the conceptual substance of the experimental and clinical neurosciences.
\end{abstract}

Shepherd Ivory Franz (1874-1933) was an important figure in psychology in the first decades of the last century, and his work has not gone unrecognized by historians of psychology. In fact, he figures prominently among the influential names in the early development of psychology (e.g., Boring, 1950; Popplestone \& McPherson, 1984; Reisman, 1976; Watson, 1971). Nevertheless, as has been noted by Marshall and Magoun (1998), his experimental work "on the cerebrum of lower primates" (p. 82) has been neglected, and as will be argued in this article, his pioneering investigations in experimental and clinical neuropsychology have been largely ignored. This article highlights the varied and significant clinical and experimental contributions made by Franz to human neuropsychology and rehabilitation that are now part of the "conceptual substance" (Frank, 1986) of the experimental and clinical neurosciences. Franz was a prolific writer, authoring more than 100 entries, including 110 articles and five books, most of which are easily accessible in large university and medical libraries. Therefore, the references to his work at the end of the paper are not meant to be an exhaustive list of his publications but are, rather, representative of his most important contributions. ${ }^{1}$

\section{Brief Biography}

Franz was born in Jersey City, NJ on May 27, 1874. His parents were D. M. William and Frances Elvira (Stod-

We express our acknowledgment to Wendy Hunt, Workers' Compensation Board Librarian, for excellent technical support. Correspondence concerning this article may be addressed to either V. A. Colotla, Workers' Compensation Board of British Columbia, P. O. Box 2132, Stn Terminal, Vancouver, BC, V6B 3T8 Canada (e-mail: vcolotla@wcb.bc.ca) or P. Bach-y-Rita, Departments of Orthopedics and Rehabilitation Medicine, and Biomedical Engineering, University of Wisconsin, Madison, WI 53706 (e-mail: pbachyri@ factstaff.wisc.edu). dard) Franz. He married Lucie Marie Niven, in London, Ontario on June 18, 1902, and they had three daughters: Theodora Niven, Elizabeth Knox, and Patricia Wilderspin. Franz obtained his first university degree, an A.B., at Columbia University in 1894 and completed his graduate work at Columbia University, with one semester at the University of Leipzig (in 1896), which offered the possibility of learning from Wundt. However, according to Franz (1932), this "ad-interim spring semester at Leipzig ... did not greatly influence me" (p. 92). Wundt was seldom seen, and instead, Franz benefited most by interacting with Meumann and Judd. His Ph.D. was awarded by Columbia in 1899, with a thesis on an exhaustive study of visual afterimages, under the direction of James McKeen Cattell (Franz, 1932).

Between 1899 and 1906, Franz trained for 2 years at Harvard with Bowditch and Porter in physiology and then taught physiology at Harvard University Medical School and Dartmouth Medical School. Between 1904 and 1907, he was a psychologist at the McLean Hospital, in Waverley, MA, where he established a psychologicallaboratory (Watson, 1953) and "acquired a working knowledge of current psychiatry and a more intimate acquaintance with the facts of abnormal psychology" (Franz, 1932, p. 106). In 1907, he moved to St. Elizabeth's Hospital, then officially known as the Government Hospital for the Insane (Franz, 1932), in Washington, DC, holding the title of Scientific Director from 1910 to 1919 and Director of the Laboratories from 1919 to 1924. Franz left Washington, DC, in 1924 to move to the West, where he became a lecturer in psychology at the University of California at Los Angeles (UCLA); the next year, he was appointed professor of psychology there, a post that he held until his death. The building housing the Department of Psychology at UCLA, Franz Hall, 
was named after him in 1940. During this time, he was also Chief of the Psychological and Educational Clinic of the Children's Hospital at Hollywood, CA.

Although much of his work, especially that related to plasticity and the rehabilitation of brain-damaged persons, was insufficiently acknowledged at the time, throughout his career, Franz received major recognition. One of the most significant, because of its rarity, was his election as Fellow (or Honorary Member, according to some biographers) of the American Psychiatric Association (at that time, the American Medico-Psychological Association), being one of the very few individuals not holding a medical degree who have been so elected. He was also a Member of the American Physiological Society and of the St. Louis Medical Society and a Fellow of the American Association for the Advancement of Science. He was a Member of the National Institute of Psychology and of the Society of Experimental Psychologists. In 1915, he received an honorary M.D. from George Washington University and an honorary LL.D. from Waynesburg College, and in 1924, he was awarded the Butler Medal by Columbia University.

Franz was very active in editorial activities of psychological journals. He was editor of the Psychological Bulletin from 1912 to 1924, editor of the Psychological Monographs from 1924 to 1927, and associate editor of the Journal of General Psychology from 1927 until his death. He was elected president of the American Psychological Association in 1920 and of the Western Psychological Association in 1927-1928. Franz died suddenly, on October 14, 1933, a few months after having been diagnosed with amyotrophic lateral sclerosis (Thomas, 1999).

\section{A Pioneer of Clinical Neuropsychology}

As Fernberger (1933) noted in a brief eulogy on the occasion of Franz's death, "much of his work bridged the gap between experimental psychology on the one hand and neurology and psychiatry on the other" (p. 741). Popplestone and McPherson (1984) described Franz's career in the following terms: "At the end of the laboratory era of psychological research on psychoses, Franz was $a$ leader in instrumentation and the leader in neuropsychology. $\mathrm{He}$ was the first psychologist who continued for an extended period of time to study psychopathology, and by virtue of this persistence he became one of the distinguished ancestors of modern apparatus and neuropsychological theory, diagnosis, and treatment" (p. 222; emphasis theirs).

Likewise, in a brief biographical note by the British experimental psychologist R. L. Gregory (1987), Franz was described as an "American neuropsychologist ... best known as the man who was largely responsible for instructing the youthful Karl Lashley in the techniques of cortical ablation." According to Gregory, Franz "was one of the most distinguished early representatives of what is now known as clinical neuropsychology"(p. 266). More recently, a biographer (Thomas, 1999, p. 406) stated that "Franz also appears to have been the first American experimental neuropsychologist and clinical neuropsychologist."
Franz's work, however, is absent from most contemporary historical descriptions of clinical neuropsychology (an important exception, however, is Finger, 1994). It is this void that the present article is intended to fill. In our opinion, Franz made significant and substantial contributionsto neuropsychology at three levels: in the conceptual arena, in the area of assessment, and in treatment (rehabilitation) techniques. He also contributed to shaping psychology as a profession, particularly in helping to delineate the boundaries between the fields of psychology and psychiatry, always advocating a friendly approach to medicine (e.g., Franz, 1912c, 1922; see also Reisman, 1976, p. 132, with respect to the views of Franz regarding issues of expertise). Furthermore, Franz (1913b) promoted the teaching of psychology in medical schools (see also Watson, 1953).

\section{Influence on Karl S. Lashley}

Franz introduced methods and techniques of experimental psychology that had been developed for the study of learned behavior - in particular, Thorndike's problemsolving box - to the study of brain-behavior relationships. Those methods were used to assess changes in behavior after removal of brain tissue in experimental animals. He preceded others in the lesion method in neuropsychology (Finger, 1994) and, as was noted earlier, influenced Karl Lashley, pushing him in "his meteorical career in experimental neuropsychology" (Bruce, 1986). In fact, his influence on Karl Lashley's career was so important that it merits some elaboration here. While completing his doctoral studies in genetics at Johns Hopkins University in Baltimore, Lashley was a volunteer assistant to John B. Watson, and 2 years after obtaining his Ph.D. he decided to make psychology his career. His work with Watson was on reflex conditioning, but in early 1916, their paths took different turns, since Watson was interested in conditioning in the development of all behavior, whereas Lashley wanted to investigate the nervous system representation of the conditioned reflexes (Bruce, 1991). The close geographical proximity of Baltimore and Washington, DC, where Franz was conducting research on what Lashley saw as the neural mechanisms of learning, was likely a factor in their collaboration. Lashley and Franz conducted five major projects together (Bruce, 1986). In the first, Lashley (1917b) found that there was no cortical control of salivation in patients with hemiparesis or hemiplegia; in the second, a study of a patient with a gunshot wound to the spinal cord (Lashley, 1917a), he demonstrated that accurate voluntary movements may be correctly accomplished in the absence of feedback from the moving organ. The third study (Lashley, 1917c) was a further elaboration of a previous study by Franz (1913a) on hand preference in animals. The final two projects were to define the rest of his career, since they involved determining the effects of frontal lobe ablations in laboratory rats after varying amounts of overtraining in a brightness discrimination task (Franz \& Lashley, 1917) and the effects of lesions in various parts of the brain on learning and retention in a 
simple maze-learning test (Lashley \& Franz, 1917). That the animals in the first study failed to show impairment in retention after the operation suggested to Lashley and Franz that the frontal lobes were not crucial in the performance of a simple motor response. The results of the second study were interpreted as meaning that no brain lesion, regardless of the area, would affect acquisition or retention of a maze habit. In 1917, Lashley moved to Minnesota, where he continued his research on the cerebral basis of learning, which he summarized years later in his wellknown book, Brain Mechanisms and Intelligence (Lashley, 1929).

\section{Conceptual Contributions}

Because of his strong commitment to objective research procedures and methods in his investigations, Franz's approach can be conceptualized as "methodological behaviorism" (Day, 1980). His objectivity bias was noted in his dislike of subjective, mental terminology when discussing his experimental findings with animals, preferring to limit his discussion to "associations of sensory experiences to motor responses" (Franz, 1902).

He was not the first to observe behavior after brain lesions. This had already been done decades before. However, he was the first to systematically use learned (instrumental) behavior as a baseline against which to compare the effects of brain lesions, using experimental methods. His experimental procedures involved different responses in environments "similar to those used by Thorndike," such as pressing a button or pulling a string that was above the animal or in front, outside of the box (Franz, 1902).

In one of his studies, which addressed the evaluation of the role of the frontal lobes in the retention of learned behavior (1906), Franz sectioned the frontal lobes of 7 macaque and 2 ringtail monkeys. He used two different tasks, one requiring a precise operant (although he did not use this word) response (turning a button $90^{\circ}$ only; more or less than this would not open the food magazine) and the other a chain of behaviors that he called the "Hurdle experiments." Franz confirmed in monkeys what he had found in cats (Franz, 1902): that destruction of the frontal lobes caused the loss of recently acquired operants (in his words, "habits") but the animal remained capable of acquiring either the same response again (relearning) or "new associations." In the case of associations that had been firmly established, by overlearning, destruction of the frontal lobes was not always followed by loss of the learned associations. For this finding, Franz advanced the suggestion that "the nervous connection of the sensory and the motor elements of the association takes place through tracts of the brain stem. The association has, therefore, more of the character of a reflex" (Franz, 1906, p. 1467). Furthermore, in discussing a monkey's failure to lose an association after removal of the frontal lobes, Franz suggested that "it is possible that the cerebral cortex was no longer used for the sensory and motor association, but that the adjustment was made in the basal ganglia" (Franz, 1906, p. 1467). He suggested that, in man, learning of games and similar activities might be explained by a trans- fer of control from the cortex to "lower centers of activities." 2 (We do not know if Franz associated this with his findings on the outcome benefits of motivating rehabilitation, which maintains higher levels of the brain involved in the motivating activity.) As was noted before, in association with Karl Lashley, he later concluded from experiments with rats that had been trained or overtrained in a maze for food that destruction of the frontal lobes did not affect the "retention of the habit" (Franz \& Lashley, 1917).

Franz was interested in both theoretical and practical human problems of recovery and was thoroughly versed in the scientific literature (Franz, 1916). The literature he evaluated included a study by Karplus and Kreidel on twostage surgical removal of the cerebral hemispheres in monkeys (which showed considerable recovery after the first hemispherectomy, and after the second side was removed, the side first affected was moved more than the newly affected side). In the same paper, he discussed a study by Robinson of a human with progressive necrobiosis almost as far as the central fissure who had none of the notable symptoms that had been supposed to be associated with lesions of the frontal portion of the cerebrum. Franz noted that some parts of the cerebrum assume functions normally undertaken by other parts when the latter are diseased, when there is time for compensation. He also discussed many other studies that demonstrated what we would identify today as brain plasticity. He interpreted a study (on the corpus callosum and epilepsy) by Karplus as supporting activation of a secondary pathway: "If one pathway be blocked there is a possibility of using one or more normally little used routes." He further noted that as the basis for Kouindjy's work on restoration of function, functional adaptation must exist in the brain, allowing nonlesioned centers to take over (Franz, 1916). Wall (1980) later would call similar phenomena the "unmasking" of previously underactive pathways after a brain lesion.

Franz was interested in brain plasticity, which he described in various forms, including "functional substitution, which is not understandable on the phrenological hypothesis" (Franz, 1923a). He questioned the generally accepted interpretations of cerebral localization studies, considering that the "new phrenology" was popularbecause it gave definiteness to diagnosis and satisfied other practical and theoretical desires, and stated that "the conception of one function for one part of the brain was too simple and too alluring to be dispensed with. Instead of the general formula that the brain is the organ of the mind, divisions were introduced and both the brain and the mind were fractioned" (Franz, 1912 b, p. 322), and he then stated that the individual parts of the brain do not work independently.

Franz further argued that cerebral localization was not fixed: He undertook a series of studies in monkeys and showed that there are considerable differences in the spatial localization of the motor areas in the brains of different animals and in the two hemispheres of the same animal. He considered that "these results, with others from other observers, have led to the formulation of a hypothesis regarding the variability of function of different brains and its relation to differences of behavior" (Franz, 1916, p. 155). 
Comparably, in discussing a case of recovery of facial movements after a successful anastamosis of cranial VII (facial) to XI (accessory) nerves, he asked, "does the patient use the cerebral motor cells for the shoulder when he smiles and, if he does, how does it come about that the mimetic movements are correctly performed bilaterally? Does he have to think about smiling with one side of his face and shrugging his other shoulder at the same time?" In regard to recovery of motor function after a stroke, he asked, "How can we account for the recovery of the ability (assuming that the cortical motor cells have been destroyed)? Surely whatever images pertained to these individual cells must have disappeared with them. And we shall then conclude that new images are created in some other part of the brain? And for the patient with aphasia, either sensory or motor, how can we reconcile the recovery phenomena with the view of image store-houses in localized cerebral cells?" (Franz, 1923a, pp. 443-444). However, he sought to reconcile differing concepts of brain organization: "Fundamentally, there is no real opposition between the phrenology of Broca and more recent writers and the whole brain hypothesis of Flourens as we have now modified it" (Franz, 1923a, p. 445). ${ }^{3}$

The neurosciences were dominated by connectionistlocalizationist concepts for more than a century, starting with Broca's 1961 classic paper (Bach-y-Rita, 1990, 1995); thus, brain-plasticity-related findings such as Franz's had little resonance with theorists, experimentalists, or clinicians during Franz's professional career. ${ }^{4}$

\section{Contributions to Psychological Assessment}

When Franz moved in 1907 to the Government Hospital for the Insane, he designed a "clinical examination procedure which could be used as a basis for the routine examination of patients" (Franz, 1932, p. 108). His procedure was adopted by the hospital in the spring of 1907, published in 1908, and expanded later into book format in 1912. This book was revised 7 years later (Franz, 1919). According to Watson (1953), Franz's procedure "was probably the first instance of routine psychological testing of psychiatric hospital patients" (p. 331), and to quote Boring (1950), "this was almost certainly the first routine psychological examination program in the world" (p. 292). In a review of the Department of Psychology at St. Elizabeth's Hospital, Ives (1970) stated that around 1907 (when Franz was director of the department), "arrangements were made with the George Washington University to have students who were candidates for the Ph.D. degree in psychology. This was the beginning of the training program." (p. 156).

In his book Handbook of Mental Examination Methods (1919, but first published in 1912), Franz describes the "methods of examination" that he had used successfully in psychological practice, "to the end that the mental examination of patients may be conducted in a more systematic and scientific manner." His method included (1) a thorough behavioral interview, aided by collateral information, (2) tests of intelligence (Binet-Simon, Army tests), (3) tests of memory, (4) tests of attention, (5) tests of speech and aphasia, (6) tests of movement, and (7) per- sonality tests (using Woodworth's psychoneurotic inventory, labeled the Personal Data Sheet; Reisman, 1976, p. 112). Although Franz's book was one of the first manuals of psychological testing to be published, McReynolds (1997) noted that one of Titchener's students, named Guy M. Whipple, had previously (in 1910) published a manual of mental and physical tests.

Congruent with modern neuropsychologicalstandards, Franz underlined the need to use norms and standards with which to compare a patient's performance. He stated that "if we are to have much advance in our understanding of the abnormal and any advance in the understanding of the normal from the study of the abnormal, many tests must be devised and applied to a number of normal, but untrained, subjects and the same tests applied to the numerous abnormal classes" (Franz, 1912a, p. 148).

It is also important to comment that Franz was interested in the "insane" and contributed a number of studies on "anomalous reaction times" in manic depressives (Franz, 1905) and different symptomatologies associated "with similar cerebral lesions in the insane" (Franz, 1915).

\section{Contributions to Rehabilitation}

At the turn of the last century, psychologists were careful not to step on other professionals' toes, and this included leaving "treatment" to physicians. Therefore, when Franz started to apply his experimental results from animal studies to human beings, he was careful to label his approach as a form of "education." He wanted to apply the principles of learning uncovered by psychologists "to ameliorate undesirable habit patterns" (Reisman, 1976, p. 176).

Two of Franz's rehabilitation-related studies, one animal and one human, stand out. In a series of experiments on monkeys, he produced hemiplegia by ablation of the contralateral motor cortex and demonstrated that the best recovery (which included extension and fine finger movements) occurred when restraint of the nonaffected arm (in order to prevent its being used for climbing and feeding) was combined with "exercises." Restraint alone was not sufficient for full recovery; "by preventing movement of the normal arm, and then 'compelling' the animal to move the paralyzed segments, and by mechanical stimulation of the peripheral nerves and of the muscles, in three weeks the animal recovered from its paralyzed condition to such an extent that the movements on the paralyzed side were judged to be normal" (Ogden \& Franz, 1917, p. 37).

Those limb-restraint monkey studies were the precursor of restraint studies, such as Whishaw and Kolb's (1988) use of a restrictive bracelet on a limb in their animal studies and the very successful clinical program developed recently by E. Taub and his associates (summarized in Taub, Uswatte, \& Pidikiti, 1999). Patients (median poststroke period of 4.1 years) underwent a 2-week period of restraint of the normal limb (held in a sling). During 10 of those days, the patients were given 6 hours of practice in using the impaired upper extremity and greatly improved in function, as measured by a series of tests. They noted extensive improvement for the restraint group in the life sit- 
uation, and these gains were maintained (and even increased) during a 2-year period of follow-up. They considered that the results demonstrated the unmasking of an ability that was already present (Taub et al., 1993).

Whereas Taub considers that the paralysis is, in large part, due to "learned nonuse," Franz considered that "it is apparent that some possibility of functional adaptation exists in the brain for certain types of movements so that when a certain 'center' and its connected muscles cannot be utilized, other 'centers' and their connecting muscles may be brought into play to bring about the desired result" (Franz, 1916, p. 154).

Franz's important study of late neurologic rehabilitation in humans was published in the Journal of the American Medical Association in 1915 with Scheetz and Wilson. They obtained voluntary motor control (with a rehabilitation program including massage, taponment, especially of the extensors, and shaking of the affected limb) in all five of their cases with paralysis of 5-20 years duration. Franz stated that "the time limit beyond which improvement may not take place cannot be set" (Franz, Scheetz, \& Wilson, 1915, p. 2153). Franz considered that because it went against neurological thought, which rejected the possibility of recovery after 2 years, the results were not well received. The attention was "in the nature of adverse criticism" (Franz, 1932, p. 100).

Although the conclusions were prescient, the studies were flawed by present (and contemporary) standards. The patient selection (including several who were demented) was not appropriate for a convincing study, and the description of the rehabilitation programs and outcomes did not provide a clear picture of the functional recovery. The methodological limitations of the Franz et al. (1915) study may have been due to the lack of adequate medical collaboration, but in any case, the structural faults have limited the value of that exciting early study of late brain plasticity, which clearly reflected Franz's understanding of late brain plasticity.

It should be noted, however, that studies in rehabilitation medicine have in general been defective. For example, few studies on the subjects of the Franz et al. (1915) paper (hemiplegia from stroke) have been methodologically adequate (dePedro-Cuesta, Widen-Holmqvist, \& Bach-y-Rita, 1992). The lack of a scientific infrastructure for rehabilitation medicine has been both a cause and a result of the neglect that followed from the domination of neuroscience by localizationists (Bach-y-Rita, 1995). Since brain plasticity fell out of favor in the last quarter of the 19th century, clinicians had had little reason to expect recovery after brain damage. Fortunately, the last 30 years have witnessed the reemergence of plasticity concepts, which, however, had never been forced out of the mainstream of Russian neuroscience; for instance, in 1932, Pavlov emphasized the importance of brain plasticity (cf. Bach-y-Rita, 1995). The proceedings of two recent excellent symposia (Levin \& Grafman, 2000; Taub, Elbert, \& Miltner, 2002) reflect the improved methodology of recent studies. Similar issues have been reviewed elsewhere (Bach-y-Rita, 1995).
Franz clearly believed in rehabilitation. He stated that "motor recovery after the production of an hemiplegia does not result if the animal is left to his own devices, and this management (or lack of management) it is unnecessary to remark is what is given to most human paralytic cases" (Ogden \& Franz, 1917, p. 44). He considered rehabilitation as a means of obtaining recovery, because "the facts which we have already collected indicate that lesions of the motor cortex or of the upper part of the pyramidal tract in man do not abolish function, but put function in abeyance until such time as the appropriate condition is present for the production of movement. We should probably not speak of permanent paralysis or of residual paralysis, but of uncared-for paralyses ... the conditions ... resemble ... disuse, rather than actual inabilities" (Franz et al., 1915, p. 2154).

Franz understood the importance of interesting, motivating rehabilitation: "Under conditions of interest, such as that of competition, the resulting movement may be much more efficiently carried out than in the dull, routine training in the laboratory" (Franz, 1921, p. 93), and he gave several examples of this approach. Although he did not specifically state that such nonmotivating rehabilitation had little carryover, Franz's understanding of the uselessness of dull, repetitive rehabilitation is related to more recent studies, such as that by Taub and Wolf (1997), who noted that there has been little written about the fact that rehabilitation, as presently practiced, has such meager carryover to real-life activities and even little carryover from one session to another. Taub and Wolf noted that this has had the effect of reinforcing the widespread impression in the physical rehabilitation field that once a patient reaches a plateau, usually 6-12 months after a stroke, further administration of rehabilitation therapy does not have useful results.

Recently, this has led to functional, motivating rehabilitation programs (cf. Bach-y-Rita, 1995, 2000). In one of these, which first appeared in the 1970s, Bach-y-Rita and his research group used an electronic pong game connected to a television set. One of the joystick controls was substituted with a device (Herring track) used in the clinic for hemiparetic persons to train arm movements. Instead of meaningless exercise, the effort to move the arm could then control a paddle (paddle size and ball speed were varied according to the capabilities of individual patients), allowing participation in a highly motivating game (Cogan, Madey, Kaufman, Holmlund, \& Bach-y-Rita, 1977). Modern versions of that device have been shown to be inexpensive and effective, which has led to the development of computeraided motivation rehabilitation devices (Bach-y-Rita et al., 2002). In the future, other forms of simple devices, gamebased Internet therapy, and other technological advances will probably be widely used in both home and institutional rehabilitation. In addition to motivation, modern researchers (e.g., Taub et al., 1993; Taub et al., 1999) consider mass practice and shaping to be important variables.

One of the explanations offered by Franz for rehabilitation after brain damage was based on the assumption that other parts of the cortex can take over functions not 
previously connected with it. He said that "the results of re-education indicate that there is some extra-cortical material which may be utilized when cortical parts are destroyed or are made functionally inoperative" (Franz, 1917a). Here, he was anticipating, of course, important research showing plastic changes in the cortex "if suitable conditions of stimulation are provided" (Franz, 1917a, p. 140). It has been found, for instance, using magnetic source imaging, that there is a larger representation of the fingers of the left hand in the cerebral cortex of string players (Elbert, Pantev, Wienbruch, Rockstroth, \& Taub, 1995), a finding suggestive of cortical reorganization according to the suitable conditions of stimulation provided to the individual. Similarly, cortical representation of the fingers in Braille readers has been found to change as a function of the perceptual experience of the individuals (Sterr et al., 1998). These studies have been reviewed in Bach-y-Rita (1995, 2000).

Franz was disappointed that his participation in commissions and extensive correspondence with military and civilian medical authorities did not lead to funding for this important field of medicine (Franz, 1917b). In his 1932 autobiography, he noted that "during the World War and after there was much talk about the re-education of the injured. The largest part of it was only an expression of maudlin sympathy or of self-aggrandizement desire.... Financial provisions for the education of the handicapped is being made, but there will remain a mass of trial-anderror efforts repeated in many communities, rather than a series of scientific experiments" (Franz, 1932, p. 103).

Franz's rehabilitation methods included procedures reminiscent of modern behavior modification. The description of his experimental findings includes chained schedules, the role of preparedness in learning, adventitious reinforcement, and social reinforcement. In his chapter entitled "The Foundation of Habits," Franz (1923b) described the behavior of cats "in a box so constructed that the reactions of the animal may be observed, but from which it cannot escape except by the manipulation of a special arranged adjustment" (p. 20). He then goes on to describe how from random movements at first, the cat eventually develops a movement "which is followed by the opening of the door of the box." Franz's attention to the animal's learned escape behavior was more like modern operant behavior theory than related to Thorndike's "stamping in" of the escape behavior. In fact, Franz makes no mention of Thorndike or of his law of effect. The following similarities to modern behavior research are evident. He underlined the importance of immediacy of reinforcement: "Another element upon which habit formation depends is the recency of the stimulus. Here we deal with the so-called delayed reaction. If the reaction be very much delayed the habit is very hard to form. The reaction must follow the stimulus closely if rapidity in habit formation is to be desired" (p. 27). He trained animals in what could now be called chained operants: "When the door is released only by a definite combination and sequence of movements, such as (a) pushing a button at the back of the box, (b) pulling a string at the corner opposite the door, and (c) standing upon a raised platform in the box, the habit is formed slowly" (p. 24). Anticipating Skinner's (1948) observations on adventitiousreinforcement, Franz (1923b) provided the following example, when making reference to the animal's "purposeful movement" to escape from the cage: "The movement may be as far removed from the situation of the confinement as the experimenter wishes. The experimenter may predetermine that he himself will open the door when the animal scratches itself. A habit of this character can readily be formed, provided there is suitable instinctive basis in the animal and also a suitable reward or a desired end to be attained" (p. 21).

Similarly, in a further paragraph, Franz antedated by 50 years the importance of biological boundaries in conditioning, when referring to the biological preparedness of the escape response. Contrast, for instance, the following description with Seligman's (1970) notion of preparedness in contemporary conditioning theory: "It has been found easy to produce a habit when the movement is one fairly definitely associated with the means of escape. It is usually more difficult to produce a habit in which the result (in the case under discussion this is escape) is not closely associated with the movement" (Franz, 1923b, p. 21).

\section{Franz's Personality}

Very little has been written on Franz as a man or as a mentor, and it is therefore difficult to appreciate his attitudes toward his time's societal values and norms or to understand his personality. As was noted earlier, Franz influenced Lashley in that he gave him direction and tools with which to go on "in search of the engram." However, we were unable to find any reference to any contact or friendship between them once Lashley left Franz's laboratory. In fact, even the terms of their initial collaboration were apparently not very warm, since according to Lashley, Franz had him, at first, photograph naked female patients at St. Elizabeth's Hospital, to see whether he was a reliable worker (Hebb, 1963). Franz has been described as "a toughminded, organically oriented, brilliant, no-nonsense researcher" (Reisman, 1976, p. 84), who apparently liked to stir controversy, as exemplified by his mocking criticism of the localizationists of his time (Franz, 1912b). However, although his challenge did cause discomfort to some researchers (e.g., Pike, 1912), Franz dismissed the importance of their reactions, not bothering to respond to them: "I have never been interested in polemic and the critiques were not answered except indirectly by much later publications" (Franz, 1932, p. 102). This apparent arrogance was likely matched with a desire to have just recognition for his findings. Shortly after he published his first results on "the retention of simple sensory motor habits" (in 1902), Franz learned that a German researcher, Kalischer, had claimed "the training-extirpation method as his own." Franz protested, "because I could see no reason why the method, if of any worth, should be labeled 'made in Berlin.' Kalischer's article was, however, as complimentary as is all plagiarism" (Franz, 1932, p. 98).

Likewise, little information remains as to the reason for his move from Washington, DC, to California in 1924. He 
was apparently unhappy with the shift in emphasis at St. Elizabeth's Hospital, "with a volcanic rise of psychoanalytic belief" and his perception that "tedious laboratory studies were looked upon as unfruitful, if not entirely useless" (Franz, 1932, p. 109). But the proverbial "straw that broke the camel's back" was apparently a personal clash with Dr. W. A. White, the hospital's superintendent and prominent psychiatrist of his time (Thomas, 1999, 2000). According to one source, in May 1924, "White reduced Franz's title and salary after another employee left a door unlocked and a brunsen [sic] burner aflame in a building under Franz's supervision. Franz quickly submitted his resignation effective 1 June 1924" (Thomas, 1999, p. 406). Franz was a proud man; he knew his worth and was not one to submit to such demeaning treatment.

\section{Conclusion}

Franz focused on observable behavior and on careful and precise measurements that could be used as baselines for behavioral interventions. Although he rejected mentalism and was antipsychoanalytic, he advocated better relationships between psychology and medicine. His most important work, however, was in neuropsychology and neurorehabilitation: (1) the use of learned behavior as a baseline to determine the effects of cerebral ablations, (2) his use of techniques derived from experimental work in animals for the training and modification of a number of behavioral problems and neurological difficulties, (3) his development of a routine psychological assessment method, (4) his insistence on the development of norms in normal, untrained individuals, as well as in abnormal populations, (5) his studies in the training (or the reeducating) of individuals with neurological conditions (e.g., hemiplegia) long after they had been considered to be at a plateau, and (6) his conceptual contributions regarding brain-behavior functions that are best understood as promoting brain plasticity as the basis for successful rehabilitations.

Franz's important findings, and even more important concepts, foreshadowed the development of brain plasticity as an important area of the neurosciences and contributed to the development of theory-based functional, motivating rehabilitation methodologies that obtain significant functional recovery in brain-damaged persons.

\section{REFERENCES}

BACH-Y-Rita, P. (1990). Paul Broca: Aphasia and cerebral localization. Current Contents, Life Sciences, 33, 18.

BACH-Y-RitA, P. (1995). Nonsynaptic diffusion neurotransmission and late brain reorganization. New York: Demos-Vermande.

BACH-Y-RTA, P. (2000). Conceptual issues relevant to present and future neurologic rehabilitation. In H. Levin \& J. Grafman (Eds.), Neuroplasticity and reorganization of function after brain injury (pp. 357379). New York: Oxford University Press.

Bach-Y-Rita, P., Wood, S., Leder, R., Paredes, O., Bahr, D., WicabBACH-Y-Rita, E. \& Murillo, N. (2002). Computer-assisted motivating rehabilitation (CAMR) for institutional, home, and educational late stroke programs. Topics in Stroke Rehabilitation, 8, 1-10.

Boring, E. G. (1950). A history of experimental psychology (2nd ed.). New York: Appleton-Century-Crofts.

BRUCE, D. (1986). Lashley's shift from bacteriology to neuropsychol- ogy, 1910-1917, and the influence of Jennings, Watson, and Franz. Journal of the History of the Behavioral Sciences, 22, 27-44.

BrucE, D. (1991). Integrations of Lashley. In G. A. Kimble, M. Wertheimer, \& C. L. White (Eds.), Portraits of pioneers in psychology (pp. 307-323). Washington, DC: American Psychological Association.

Cogan, A., Madey, J., Kaufman, W., Holmlund, G., \& Bach-YRitA, P. (1977). Pong game as a rehabilitation device. In C. G. Warren (Ed.), Fourth Annual Conference on Systems and Devices for the Disabled (pp. 187-188). Seattle, WA: University of Washington School of Medicine.

DAY, W. F., JR. (1980). The historical antecedents of contemporary behaviorism. In R. W. Rieber \& K. Salzinger (Eds.), Psychology: Theoreticalhistorical perspectives (pp. 203-262). New York: Academic Press.

dePedro-Cuesta, J., Widen-Holmqvist, L., \& Bach-Y-Rita, P. (1992). Evaluation of stroke rehabilitation by randomized controlled studies: A review. Acta Neurologica Scandinavica, 86, 433-439.

Elbert, T., Pantev, C., Wienbruch, C., Rockstroth, B., \& Taub, E. (1995). Increased cortical representation of the fingers of the left hand in string players. Science, 270, 305-307.

Fernberger, S. W. (1933). Shepherd Ivory Franz, 1874-1933. Psychological Bulletin, 30, 741-742.

FINGER, S. (1994). Origins of neuroscience. New York: Oxford University Press.

FLOURENS, P. (1842). Recherches expérimentales sur les propriétés et les fonctions du système nerveux dans les animaux [Experimental investigations of the properties and functions of the nervous system in animals] (2nd ed.). Paris: Ballière.

FRANK, R. G. (1986). The Columbian exchange: American physiologists and neuroscience techniques. Federation Proceedings, 45, 2665-2672.

Franz, S. I. (1902). On the functions of the cerebrum: I. The frontal lobes in relation to the production and retention of simple sensory-motor habits. American Journal of Physiology, 8, 1-22.

Franz, S. I. (1905). Anomalous reaction-times in a case of manicdepressive depression. Psychological Bulletin, 2, 225-232.

FrANZ, S. I. (1906). Observations on the functions of the association areas (cerebrum) in monkeys. Journal of the American Medical Association, 47, 1464-1467.

Franz, S. I. (1912a). Experimental psychopathology. Psychological Bulletin, 9, 145-154.

FranZ, S. I. (1912b). New phrenology. Science, 35, 321-328.

FranZ, S. I. (1912c). The present status of psychology in medical education and practice. Journal of the American Medical Association, 58, 909-911.

FranZ, S. I. (1913a). Observations on the preferential use of the right and left hands by monkeys. Journal of Animal Behavior, 3, 140-144.

Franz, S. I. (1913b). On psychology and medical education. Science, 38, 555-566.

Franz, S. I. (1915). Symptomatological differences associated with similar cerebral lesions in the insane. Psychological Monographs, 19 (Whole No. 81), 1-79.

Franz, S. I. (1916). The functions of the cerebrum. Psychological Bulletin, 13, 149-173.

Franz, S. I. (1917a). Cerebral adaptation vs. cerebral organology. Psychological Bulletin, 14, 137-140.

Franz, S. I. (1917b). Report of Committee on Reeducation Research. Psychological Bulletin, 14, 416-418.

Franz, S. I. (1919). Handbook of mental examination methods (2nd ed., rev. and enlarged). New York: Macmillan.

Franz, S. I. (1921). Cerebral-mental relations. Psychological Review, 28, 81-95.

Franz, S. I. (1922). Psychology and psychiatry. Psychological Review, 29, 241-249.

Franz, S. I. (1923a). Conceptions of cerebral functions. Psychological Review, 30, 438-446.

Franz, S. I. (1923b). Nervous and mental re-education. New York: Macmillan.

Franz, S. I. (1932). Autobiography. In C. Murchison (Ed.), A history of psychology in autobiography (Vol. 2, pp. 89-133). Worcester, MA: Clark University Press.

FrANZ, S. I., \& LASHLEY, K. S. (1917). The retention of habits by the rat after destruction of the frontal portion of the cerebrum. Psychobiology, 1, 3-18. 
Franz, S. I., Scheetz, M. E., \& Wilson, A. A. (1915). The possibility of recovery of motor function in long-standing hemiplegia. Journal of the American Medical Association, 65, 2150-2154.

GREGORY, R. L. (Ed.) (1987). The Oxford companion to the mind. Oxford: Oxford University Press.

Heвb, D. O. (1963). Introduction to Dover edition. In K. S. Lashley, Brain mechanisms and intelligence (pp. v-xiii). New York: Dover.

IvEs, M. (1970). Psychology at Saint Elizabeth's: 1907-1970. Professional Psychology, 1, 155-158.

LASHLEY, K. S. (1917a). The accuracy of movement in the absence of excitation from the moving organ. American Journal of Physiology, 43, 169-194.

LASHLEY, K. S. (1917b). Changes in the amount of salivary secretion associated with cerebral lesions. American Journal of Physiology, 43, $62-72$.

LASHLEY, K. S. (1917c). Modifiability of the preferential use of the hands in the rhesus monkey. Journal of Animal Behavior, 7, 178-186.

LASHLEY, K. S. (1929). Brain mechanisms and intelligence. Chicago: University of Chicago Press.

Lashley, K. S., \& Franz, S. I. (1917). The effects of cerebral destruction upon habit formation and retention in the albino rat. Psychobiology, 1, 71-139.

LeVIN, H. S., \& GRAFMAN, J. (Eds.) (2000). Cerebral reorganization of function after brain damage. New York: Oxford University Press.

Marshall, L. H., \& Magoun, H. W. (1998). Discoveries in the human brain: Neuroscience prehistory, brain structure, and function. Totowa, NJ: Humana.

McReynolds, P. (1997). Lightner Witmer: His life and times. Washington, DC: American Psychological Association.

OGden, R., \& FRAnZ, S. I. (1917). On cerebral motor control: The recovery from experimentally produced hemiplegia. Psychobiology, 1, 33-49.

Pike, F. H. (1912). A defence of the "new phrenology." Science, 35, 619622.

Popplestone, J. A., \& McPherson, M. W. (1984). Pioneer psychology laboratories in clinical settings. In J. Brozek (Ed.), Explorations in the history of psychology in the United States (pp. 196-272). Cranbury, NJ: Associated University Presses.

ReISMAN, J. M. (1976). A history of clinical psychology (rev. ed.). New York: Irvington.

Seligman, M. E. P. (1970). On the generality of the laws of learning. Psychological Review, 77, 408-418.

SKINNER, B. F. (1948). "Superstition" in the pigeon. Journal of Experimental Psychology, 38, 168-172.

SQuire, L. R. (1994). Declarative and nondeclarative memory: Multiple brain systems supporting learning and memory. In D. L. Schacter \& E. Tulving (Eds.), Memory systems 1994 (pp. 203-231). Cambridge, MA: MIT Press.

Sterr, A., Muller, M. M., Elbert, T., Rockstroth, B., Pantev, C., \& TAUb, E. (1998). Changed perceptions in Braille readers. Nature, 391, 134-135.

TAub, E., Elbert, T., \& Miltner, W. H. R. (2002). Neurorehabilitation and remediation: The melding of basic research in neuroscience and behavioral science to produce advances in therapeutics-An impending paradigm shift. Manuscript in preparation.

Taub, E., Miller, N. E., Novack, T. A., Cook, E. W., III, Flemming, W. C., Nepomuceno, C. S., Connell, J. S., \& Crago, J. E. (1993). Technique to improve chronic motor deficit after stroke. Archives of Physical Medicine \& Rehabilitation, 74, 347-354.

Taub, E., Uswatte, G., \& Pidikiti, R. (1999). Constraint-induced movement therapy: A new family of techniques with broad application to physical rehabilitation-A clinical review. Journal of Rehabilitation Research \& Development, 36, 1-8.

TAub, E., \& Wolf, S. L. (1997). Constraint induced techniques to facilitate upper extremity use in stroke patients. Topics in Rehabilitation, $\mathbf{3}$, $38-61$.

Thomas, R. K. (1999). Franz, Shepherd Ivory. In J. A. Garraty \& M. C. Carnes (Eds.), American national biography (Vol. 8, pp. 405-406). New York: Oxford University Press.

Thomas, R. K. (2000). Franz, Shepherd Ivory. In A. E. Kazdin (Ed.), En- cyclopedia of psychology(Vol.3, pp. 396-398). New York: Oxford University Press.

WALL, P. D. (1980). Mechanisms of plasticity of connection following damage in adult mammalian nervous systems. In P. Bach-y-Rita (Ed.), Recovery of function. Theoretical considerations for brain injury rehabilitation (pp. 91-105). Lewiston, NY: Hans Huber.

WATSON, R. I. (1953). A brief history of clinical psychology. Psychological Bulletin, 50, 321-346.

WATSON, R. I. (1971). The great psychologists(3rd ed.). Philadelphia: Lippincott.

WhishaW, I. Q., \& KolB, B. (1988). Sparing of skilled forelimb reaching and corticospinal projections after neonatal motor cortex removal or hemidecortication in the rat: Support for the Kennard doctrine. Brain Research, 451, 97-114.

\section{NOTES}

1. A complete list of Franz's publications is available from either author.

2. Contrast this explanation with the contemporary analysis of declarative (or explicit) and nondeclarative (implicit) memory systems as depending on the hippocampal system and the basal ganglia, respectively (e.g., Squire, 1994, pp. 215-216)

3 . Franz's comments here reflect the usual indifference of Englishspeaking neuroscientists to the French scientific literature. Broca was not in any way a phrenologist:His pioneering study of cerebral localization led to the dominance of the neurosciences by localization studies, but there is no evidence that he ceased to be a broadly conceptual scientist. The tone of Broca's reports suggests that he would have avoided the pitfalls of strict localizationism (Bach-y-Rita, 1990, 1995).

Flourens published an incredibly modern book entitled Recherches Expérimentales Sur Les Propriétés et les Fonctions du Systeme Nerveux Dans les animaux vertébrés in 1824 (extensively revised in 1842) demonstrating (although he did not draw the now obvious conclusions), among many other physiological principles, that functions are localized in individual parts of the brain but that, following extensive brain lesions, lost functions can be regained without the regrowth of the ablated part of the brain (animals were observed for periods up to 1 year). However, he opposed the teachings of Gall, was responsible for a hiatus in development in the concept of cortical localization, and anticipated the holistic theory of brain function. Flourens considered that although the different parts of the nervous system have specific properties, appropriate functions, and distinct actions, they nevertheless constitute but a single system: One stimulated point in the nervous system stimulates all others, one weakened point weakens all; they have reaction, change, and energy in common. Unity is the outstanding principle that rules. It is everywhere, it dominates everything. The nervous system, therefore, forms but a single system.

It is often ignored that his studies also supported cerebral localization: Following a series of brain ablation experiments, he concluded that the cerebral lobes are the exclusive site of all sensations and intellectual functions and that each sense organ has a distinct origin in the cerebral mass. He noted that the cerebral lobes, the cerebellum, and the quadrigeminal bodies may lose a portion of their substance without losing the exercise of their functions and that, following brain lesions, animals are able to recover functions after having lost them completely.

Thus, Flourens may have been the first to publish on the reorganization of function after brain damage in experimental animals, and he was probably also the first scientist to accept the coexistence of cerebral localization and brain plasticity, with functional recovery based on reorganization of the brain. It has taken the field 150 years to appreciate these concepts (Bach-y-Rita, 1995).

4. Space limitations preclude a thorough discussion of the state of neuroscience at the time of Franz's work. The reader is referred to Finger's (1994) excellent work on the history of neuroscience, particularly chapters 4,23 , and 29 .

(Manuscript received January 28, 2002; revision accepted for publication May 1,2002.) 